\title{
Transcript of Proceedings
}

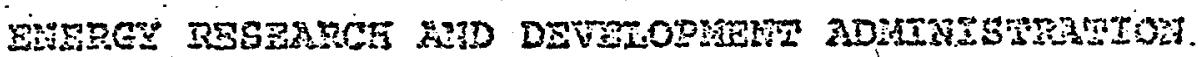

EREREY TECHNOLOCINS FOR THE VIEST

HORTSHOP:

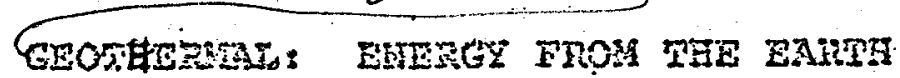

Sax Ptancisco, California

Twasday, 21 septanber 1976

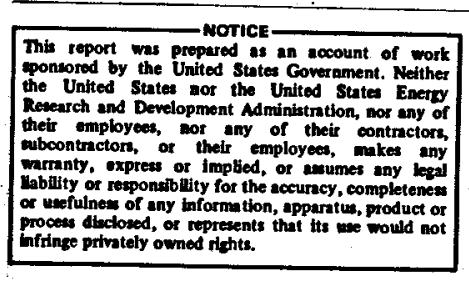

ACE - FEDERAL REPORTERS, INC.

Official Reporters

415 Second Street, N.E.

Washington, D. C. 20002

Telephone:

(202) $547-6222$

NATIONWIDE COVERAGE 


\section{DISCLAIMER}

This report was prepared as an account of work sponsored by an agency of the United States Government. Neither the United States Government nor any agency Thereof, nor any of their employees, makes any warranty, express or implied, or assumes any legal liability or responsibility for the accuracy, completeness, or usefulness of any information, apparatus, product, or process disclosed, or represents that its use would not infringe privately owned rights. Reference herein to any specific commercial product, process, or service by trade name, trademark, manufacturer, or otherwise does not necessarily constitute or imply its endorsement, recommendation, or favoring by the United States Government or any agency thereof. The views and opinions of authors expressed herein do not necessarily state or reflect those of the United States Government or any agency thereof. 


\section{DISCLAIMER}

Portions of this document may be illegible in electronic image products. Images are produced from the best available original document. 


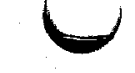

tor

WORKSHOP

10

11

12

13

14

15

16

17

18

19

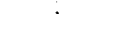

\section{GEOTHERMAL: ENERGY FROM THE EARTH}

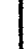

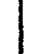


1

SPEAKER

Dr. John W. Shupe, Chairman, College of Engineering,

4

5

6

7

8

9

.10

11

12

13

14

15

16

17

18

19

.20

$\cdots$

Professor Hamilton Hess, University of San Francisco

Robert G. Lacy,

Mechanical Engineer, San Diego Gas \& Electric

Dr. Tsvi Meidav,

President, Geonomics, Inc., Berkeley, Ca.

Donald Finn,

Managing Director, Geothermal Energy Institute

John Arlidge,

Assistant to the Vice President,

Nevada Power Company

Jim. Bresee,

Acting Director, Division of Geothermal

Development, ERDA
43

2

PAGE

4

.13

20

25

32

46 
MR. VAIENTINE: We probably ought to get under way.

In doing that, let me explain, for those of you who may have wished to talk about fossil fuels or fusion, or some of the other alternative sources of energy, that this is the session on geothermal energy, and we will discuss those subjects directly related thereto, probably.

The basis foremat is similar to that which you have experienced earlier today, if you hae been able to participate. If you have not, it is ten-minute presentations by each of the members on the panel. And like I said, around 12:00 this morning we will get to ideas and concerns that you may have as people in the audience.

Let me assure you that there will be every intention to maintain the ten-minute limitations up here, and to allow you, the audience, all the opportunity that you should desire, even if we go beyond the specified hour, to discuss with those people who are capable of answering your questions, thos concerms that you may have.

And I would like to start off, if I could, with a slide presentation. Recognizing that this room is somerhat warm, and not desiring to have too many people checking their eyelids for holes, we should start off with the last speaker first. That would be John Shupe, Chairnan, College of Engineering, University of Hawaii, who has a brief slide presentation 
to back up his topic. John?.

DR. SHUPE: Thanks. This is a pleasant surprise. I

3

We know we have magma in Hawaii. We hope that we have other forms. Our initial program was to investigate these.

Next silde, please.

As many of you are aware, Hawaii was formed from the northwest to the sotheasterly direction. This is the big island of Hawail, which is down in the southeastern portion, so it is the newest. similarly, the island was formed in the same direction. Five vocanoes - Kohala the oldest, next Manna Kea, then Hualalai, then Mona Loa and Kilauea. Both Hanna Loa and Kilauea are still active volcanoes, and. we reason that the likelihood of finding near-surface heat 
2

3

4

5

6

7

8

9

10

11

12

13

14

15

16

17

18

19

. 20

21

would be greatest in the vicinity of recent volcanology, which vas not too brilliant on our part. So we did concentrate most of our reconaissance in this area, but ultimately hope to proceed up the island chain.

Next slide, please.

This is an overview of that area with lianna Loa in

the background, Kilauea in the foreground, Halemaumau crater, which is tine vapor coming at this time, to indicate the complexity of the geological situation there.

Next slide, please.

We ran a variety of geophysical and geoscience surveys -- the infrared where molten magma appeared. It showed up kind of warm, which we suspected. He found no surprises in these.

Next slide, please.

We ran a variety of others. This is a dipole resistivity which indicates certain highs do:n in the puna area. Next slide.

We also looked into some mathematical modelling with engineering, both from reservoix prediction, as well as some. of the environmental characteristics, if we penetrate the fresh water lens.

The next slide, then, I believe is a summary of the various tasks that we completed in phase. I with a variety of geophysical surveys over on the left side. We developed in 
1

parallel, then, aș I say, some of our engineering and en-

vironmental. Socio-economic was a very important aspect of

this.. We indicated four years ago that this would probably

hold up the development of geothermal. We still predict that it will.

Next slide, please.

The funding that we got from this -- the amount is

not important -- but it does indicate the variety of sources

that we had. This, from the beginning, has been a cooperative

venture. That has been a very gratifying aspect of it. Our

state legislature put a couple of hundred thousand dollars in

the 72 fiscal budget for geothermal research, and this was

well before the crisis came along. So from my bias, I feel it was a rather progressive step for a legislature to take.

We did get some NSF matching and started the program, then, in the sumner of '73. So that I am giving is roughly

a three-year progress report, then. NSF picked this up for another year, and then ERDA took the program over in January of 75. He did have some Hawaiian Electric Company money that went into this initial one.

The next slide shows, then, our initial driliing

22 phase, where the legislature put another half milion dollars

23 into drilling. ERDA came up with $\$ 1,064,000$, Hawailan Electrid,

24 another $45^{\prime}$, which is a small amount, but it was helpful to.

25 us in getting the ground prepared while ve were doing a little 
bit of wheel spinning on the other.

Since then, we have spent an additional $\$ 800,000$, again primarily of ERDA funding; each incremental "success" seems to require more funds, as the hole heats up, and we need to shove in a slotted liner, or something of this nature. Everything requires more money. The state has come up with. an additional $\$ 65,000$, and another private group. But the bulk of the funding has come from ERDA for this program. Hext slide, please.

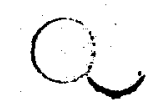

Over along the right along our puna rift is where, after two years of geophysical surveys, we decided was the logical point to put this.

Next slide, please.

At the dedication, John Team (?) came out to

help dedicate it. This represents the various groups. At our right of Team is our state Energy Resources Coordinator and the mayor of the big island. So in Hawaii, natural energy is extremely important, so we do get a good turnout. We had the usual Hawaii blessing, which apparently worked. He had a 7.2 earthquake about 15 miles from this about three weeks later, and the rig stood beautifully.

Next slide, pleaśe. This is an aerial vier. It is on a recent, 1955

Elow. 
We started, then, in November of 175, immediately ran into this tough basaltic rock and started grinding away before we had any load on the bit, and used up tremendous amounts of money.

Next slide.

We finally did get a 30-inch surface casing. Next slide.

And we had rather a conservative casing progran. We

had New Zealand consultants for this project and we had

been informed that there was no way that we could maintain the circulation. So this casing program that was developed was with this assumption. Actually, we did manage to maintain circulation after we got below 400 feet, and had it throughout.

But it is, those of you recognize this is a rather complicated casing program -- and particularly in that top 400 feet, we ground and ground away in expanding out to 26 inches in order to get that casing in.

\section{Next slide, please.}

Once we got below our production casing at 2,200

feet, we úsed this eight-and-a-half button bit, and we did have excellent progress then. We drilled the bottom 4,200

feet in less than three weeks with arilling and coring.

24 So that went reasonably well. 
Is re got to the bottom of this hole -- well, we

cored throughout. This was a scientific hole, with NSF and ERDA and state funding in it. So we took cuttings on ten-foot intervals and cores -- about ten of these. Our total depth went to 6,450 feet. We started at 600 feet above sea level, so we went somewhat more than a mile below sea level. Next slide; please.

As we got to the bottom, we were somewhat pleased to find the hole finally started to warm up. At that time, the decision was reached; as I indicated, to go ahead and proceed with clearing out the mud and putting in a slotted liner and proceeding with the well testing. This is merely a shot of the slotted liner.

$$
\text { Next slide, please. }
$$

We did go ahead and complete the well head.

- Next-slide.

We put in the proper gauges and on July 22, we had then a flow test.

Next slide, please.

This first slide was taken two minutes, at 1402, aftex we opened the valve. This is a six-inch vertical valve. As I say, we had the New zealand consultants on this. We were using the Russell James method which requires sonic flow. We had excellent temperature in it as vell. ve had about $600^{\circ}$ farenheit that we had measured do:m there. But there was 
sone concern that this would be a tight hole. ine had very little loss of circulation during. the driliing, and some of our preliminary punp tests -- we had had very little drop in pressure. So we felt that this would be a tight hole. In. fact, sone had predicted that it would blow itself dry in less than 15 minutes.

So this was one reason we vere using a relatively

Next slide, please.

minutes into.it, and you can notice that this plume gets progressively smaller.

Next slide, please.

This was about 15 minutes into the test. As I.say,

with sonic flow, there was -- even four hours later -- there was a tremendous amount of energy noise that came from the

17 well. The decibel count was about 120 on a C scale 200 feet from the well itself, which is about the same as a 747 at takeoff. So these pictures certainly do not give any indication of the energy that was coming from this vell. ivext slide, please. We did open the horizontal valve briefly, primarily to see that all of our valves were vorking correctly, and 24 some what of a PR shot. It proved very little. 
SPEAIER: How many minutes after was that horizontal

2 shot. taken?

DR. SHUPE: That vas about 15 minutes also. I will

have one curve showing the pressure drop, and you can see where that blip conies in.

This, then, was taken about an hour into the test. Next slide:

This sho's what our pressure variation was. Next slide, please.

This is wellhead pressure. We also had lip pressure

11 which James takes. We had a very. high immediate buildup to close to $500^{\circ} \mathrm{psi}$, then a very rapid drop. I do not know what that first transient is up there around 400 . The second one down here is when we opened that horizontal valve for a five-minute period. We did have that blip there. But then it built back up.

And of course, whether it has leveled off after

four hours or not, of course, we really do not know yet. But with the rather rough measurements that we had, it was at least somewhat encouraging, because at the end of our fourhour period, we still had a rate of flow of roughly - . the estimate was 220,000 pounds per hour, estimated an enthalpy of roughly 650 . With an enthalpy of $650 \mathrm{Btu}$ 's per pound, the estimate of about 15 percent conversion rate was still roughly five megawatts of power from this thing at the end of 
four nours.

\section{Next slide, please.}

This was a shot at the end of the four-hour period. The last slide then, please.

This shows a fairly stable temperature variation in that well, roughly a month later. We took Custer pressure and temperature runs down the hole at one-week intervals from there on in, and this is a fairly stable condition inaicating a high temperature range somewhere in the neighborhood of $300^{\circ}$ Centigrade, or $600^{\circ}$ farenheit occurs from about 3500 feet on down. So we probably have rather a small microfracture there, a relatively low permeability, but over roughly about a 2,500 foot column. So there might be reasonable rate of flow from this:

We took a variety of samples of steam and water from the well during the test. The quality surprised us tremendousIy. It is pretty close to fresh water, much better than the quality of the wells in the vicinity. so in discharging it, we are actually improving the quality of our five wells around it. We are going ahead and running more tests on both air 22 steam and water samples that we took, and are in the process 23 of designing a silencer and will start, then; a nore compre24 hensive flow test lasting, probably, four to six weeks, around 25 November 1 
It is premature to know whether we have a commercial

winner there, but we are sufficiently encouraged that we are

working through the state with the Hawaiian Electric Company and otiners, while we are going through these testing processes. to start parallel work in a variety of other areas. Dut I have used up my time, so I will not discuss those. Thank you.

MR. VALENTINe: Thank you very much. That was

very interesting. And following that, and after having seen

the beautiful island of Ilavaii and what you can do in that kind of surroundings, I would like to ask, if I could, Dr.

11 Hess, from the University of San Francisco. Just prior to introducing him, I would like to indicate that following him vill be Bob Lacy. I understand, Bob, you have some slides.

14 And if we could have that slide presentation ready, tinen -Prof. Hess?

PROF. HESS: We are going to move from the technical to the philosophical, a change of pace. And I would say that

18 the speaker following, who will be having some slides, I pre-

19. sume of current technologies and geothermal operations might.

20 weil be used as illustrative material for one part of my o:n

21 presentation, speaking of some of the environmental problems of geothermal.

The past several years have witnessed a growing en24 thusiasm for the development of geothermal resources. Facil-i- 
1

2

3

4

5

6

7

8

9

10

11

12

13

14

15

16

17

18

19

levels. A variety of agencies have been involved, Federal and state; AEC, NASA, Department of Defense, Bureau of Reclamation, Department of Interior, and nov ERDA, have all been actively involved.

Eut you have little actual development of geothermal resources that has taken place. This fact is a source of embittering frustration to committed advocates of geothermal energy, and the reasons behind it are being sought in a number of governmentally sponsored studies and industry analyses. It is my intention to offer a brief analysis of the situation from the standpoint of the environmental interest sector. policy and energy industry commitments, geothermal is still an exotic alternative, or at best, a marginal energy source. And it would seem to be a marginal energy source into the foreseeable future. In terms of world politics and economics, petroleum interests dominate the energy sector, and by sheer inertia, if nothing else, exclude the serious entrance of competitive sources.

In the United States, the commitment of the rederal government and the utilities to nuclear power has led to the effective relegation of geothermal, together with solar and other undeveloped energy sources, to the status of optional extras. In my opinion, these factors will continue to prevent the development of the favorable conditions for serious 
governmental or marketplace interest in geothermal, unless or until radical policy shifts are brought about.

with regard to our management of the depleting fossil fuels and a de-emphasis of the nuclear alternative. The development (of of a climate favorable to geothermal will also require financial incentives which are now largely lacking, and a demonstration - of the capability of technology to convert earth heat energy to commercially usable energy, and the proving of resource reserves to be both vast in quantity and widespread in availability over an extended period of time.

Fe are here faced with a chicken and an egg situation.: Technological development and the proving of reserves will not take place in the energy market without either the commitment, shifts having àlready taken place, or without subsidized financial incentives. 'Government financing and perhaps also government management are needed to move the situation from dead center. are part of the problem. We are brought inescapably back to the matter of orientations and attitudes which are basically cultural in nature. The only discernible solution to the problem is also cultural: growing awareness throughout world society that the continuing and unbridled consuription. of petroleum and coal for energy production is unjustifiable, 
and tinat the nuclear option is too fraught with hazards to be worth the risk.

Turning to more concrete issues which I believe affect geothermal development at the present time, it is Ireçuently charged tilat bureaucratic delays and environmental concerns are strangling the infant industry. I would point out that bureaucracy knows no favorites, and that environmental considerations are touching. incustrial activity, and indeed, most human activity across the board.

Many of the bureaucratic checkpoints themselves have

been instituted in the interests of environmental protection.

No one is particularly happy with the way that the mechanisms

of environmental protection are presently operating. They

need to be streamlined in certain vays. Find on the other

hand, they may need to be made more effective in a number of

respects. But they are undoubtedly here to stay. Energy

production and other forms of industrial activity no longer haye unquestioned priority.

They. have to be balanced in a system of trade offs,

with" the interests of a clean and healthy planet and of the

demands of land use. It has been the fate of geothermal to have made its effective debut at nearly the same time that the National Environmental Policy Act and the California

Environmental Suality. Act were established as law. 
and restrictions virtually unknown in earlier years to other forms of energy resource production. In my opinion, the two most serious obstacles facing geothermal resource development, from the governmental sector, are the result of institutional malfunctions on the Federal, state and local levels.

These are found in the environmental impact reporting process and in the land use question. Environmental impact reports or statements are required for all major actions on Federal lands and all actions on state and private lands in the state of California which have significant adverse impact on the environment. Geothermal operations unquestionably are actions which have significant impact. Environmental impact reports are informational documents which are intended to assist permit granting agencies to make environmentally responsible decisions concerning projects which they are called upon to license.

Although improvement has been notable incertain respects during the past year, we are still in a growing pains stage in the implementation of the impact reporting process.

Prospective developers are concerned with the time that the process takes, and the environmentalist sector and potentially affected public are concerned with the objectivity and the adequacy of the reporting and whether the decision makers are in fact taking environmental findings into account. 
areas of giothermal potential on Loth Federal and private

2

3

4 lands, and state lands as well, is a major governmental malfunction, and consequent point of abrasion in relation to geothermal project proposals. Many areas offer no particular land use problems. Other areas are moderate in their land use sensitivities. But some areas are highly sensitive to the intrusion of an industrial use in competition with residence and recreation and with natural values.

A concerted and cooperative planning program on the

Federal, state and löcal levels, with structured public participation in that program, is needed to resolve the land use conflicts which have already arisen and which will continue to arise in geothermal resource areas. Such planning should have in-built flexibility to accommodate the results. of future technological advance, which will presumably allow geothermal operations to take place in closer proximity to non-industrial use, areas than is now the case.

The land use problem in geothermal is made all the more acute by its heavy land requirements in areas of development. Geothermal operations effectively occupy one-and-a-half square miles for every 100 megawatts produced. If, for example, California's electrical energy needs are 100,000 megawatts by the year 2000 , and if one-third of it were to be supplied by geotisermal, 1,500 square miles of land would be 25 required. 
Considering the fact that geothermal energy must ie developed where it is availaile, land use problems nay rapidly jecome unmanagcable in the absence of effective planning if developrient escalates. And that is particularly in ligit of the fact that geothermal resource areas are frequently in the areas of other values.

Geotinermal has been frequently hailed as a clean source of energy. Those who are faniliar with it know that it has its own problems. Geothermal has certain advantages environmentally. But it also has problems. Present problems include extensive cut and fill operations in hilly terrain with consequent land form alternation, visual impact, erosion, domstream siltation, water pollution from accidental spillage of geothermal brines, condensate or arilling muds, odor and air pollution from hydrogen sulfide, other non-condensables, and particulate matter.

Possible long-term adverse effects on living organisms in regions of development from these gasses and chemicals remains a problem. Industrial. noise, visual impact, are also

20 problems involved.

If geothermal power and the utilization of geothermal resources in general has defined the kind of public acceptance that it needs to succeed, indeed, if it is to be allowed to 24 make the contribution to the energy supply that is capable of making, the means for its production, I believe, ruust be 
revolutionized within technology so as to eliminate or drastically reduce its present impacts in the locale of production. And certainly the impacts of geothermal development are subject to such progress in their elimination. This is certainly the point in history when priority attention should be given to the environmental problems in relation to geothermal for geothermal to find that acceptance which it source. Thank you.

HR. VALEININE: Thank you, Prof. Hess. Hot only did

11 I stumble on your name, but I forgot to give you the recngnition due as the chariman of the geothernal section of the Sierra Club, which I am sure is an important guardian of the environment.

Nert, I would like to introduce, as I said I would, Bob Lacy from San Diego Gas and Electric; who has another one of those demonstrations for you, if you would bear with us. IIR. LACY: Thank you, Denny. I would like to thank ERDA, too, for the opportunity to tell you about what we are doing in the Imperial valley. What I would like to do is to

21 show you some slides of a ten-megawatt binary cycle test facility that is now in operation in the Inperial Valley. If I can have the first slide. Thank you. We started working in the Imperial 
develop geothermal resources about six years ago. The purpoise of this presentation, as I indicated, is to give you a brief history of our activities and to give you just a minute or so about some of our future plans. To give you some geographic perspective, the Imperial Valley lies east of our service territory. The residents of that area are served by the Imperial Irrigation District. Our service territory is outlined in yellow on this slide. The distance from San Diego to our perspective sites is in the neighborhood of 120 to 140 miles, so that is one obvious reason why we are particularly interested in geothermal energy.

At the present time, though, no substantial transmission exists between these sites and our service territory. Consequently, energy from the first generating unit that We plan for the Valley will probably go to the customers of IID. Our activities are directed toward the development of four sites in the Valley. We and our partners have leases of varying size at each of these sites. We have done substantial work at two of them, Niland and Heber, and have started work. on a third, East Hesa.

the company, acting through New Albion Resources Company, a

Our efforts started back in January of 1971; when subsidiary of SDG and E, joined lagma pover to begin drilling 25 vells. Vells vere drilled in two areas, woth wiland and lieber $j$ 
These wells show promising characteristics and additional

wells were drilled to help define, as best we could at that time, the extent and potential of the resources we were dealing with. In 172 , flow testing at Niland was conducted for about ten days in an attempt to determine the reservoir, information related to flow characteristics, temperature staenough, and I suppose we were naive enough, to warrant further testing. We also decided at this time to begin the detail design for a test facility, a nominal ten-megawatt facility, to determine the process and the equipment most suitable for economical and reliable power generation with this energy source. that the system involves flashing the brine to steam in four stages, scrubbing the steam, and passing that scrubbed steam through heat exchanges where it gives up its energy to

After two years of field tests using a variety of cyciles and truck mounted equipment the design of the existing facility, began in November of 74 , and was completed in early 1975. I am not going to go into this cycle. If anybody has any questions later, we can throw this slide up again, and I will spend some time on it. Suffice it to say 
isobeutane, which is the working fluid. The isobeutane circulates in a closed 100p, and it is in return cooled by. irrigation water.

Site preparation for the facility construction was started in April of last year and completed in June. The installation of the transmission line to the site was completed on June 4 . Ve need approximately two-and-a-half megawatts of outside power to drive the pumps, as well as othen miscellaneous equipment. At this time, we have not installed a turbine or a generator. However, the transmission line has the capability of handling the net output of the plant, or about seven-and-a-half megawatts; should we decide to go ahead and install a turbine generator. This power would go to IID for distribution in the Valley. Construction of the facility itself was started in June of last year and is. now complete. Equipment and systems started in. December of last year, and we have now commenced an 18-month operation period of the facility. The major areas of investigation that we are exploring or expect to encounter during the operation of the facility are first, to determine the temperature and the pressure at which brine can be extracted over long periods of time. This information will indicate the amount of energy present in the reservoir. secondly, it will be to determine the performance. of the reservoir under extraction and reinjection conditions. 
1

And we are reinjecting the spent brine here. Third, to overcome the loss of production due to scaling in the well itself; fourth, to overcome erosion in scaling in the equipment -- that is, the hardivare above ground -- and to improve the quality. of steam separation; finally to develop metallurgical techniques needed to withstand the abrasive nature of the brine that we are dealing with.

The estimated cost of the facility, including 18 months of test programs -- and by the way, this picture was taken during the dedication of the facility on June 4 -- the cost of the facility, including the 18 months of operation, is approximately $\$ 8$ million. In July of last year, ERDA joined the company in a joint project agreement for the construction and operation of the facility. The costs are shared 50-50 by the company and ERDA.

The facility is owned and managed by the company, and in addition to jointly funding the experiment, ERDA is providing technical support, and I cannot underestimate the importance of that support to this operation, in the form of redirecting portions of its current R\&D program, as well as carrying out specific new studies of problems which we encounter. The company and ERDA will jointly analyze and report the results of the technical program for public use.

$$
\text { In addition, ERDA is conducting environmental }
$$
studies -- and I just penned this in, Dr. Hess -- to support 
this operation, first to identify baseline conditions and finally, to assess the impact of the facility on the environment. Is I indicated, the facility is in operation 24 hours a day, knock on wood. The results of the operation to date have been very encouraging, more encouraging than we had anticipated. our plans for the future, our goals, at least: first, the tion unit to be located at the Heber site for operation in

A few words about our -- this. is my company, now -start-up and testing of the facility that I just talked about; secondly, the construction of a 50-megawatt demonstralate 1980; and finally, the construction of two 50-megawatt commercial units at Heber and Niland by operation by 1982 . This sounds rather optomistic, but we have found that without setting goals, you do not get anything done. And these are our goals. Thank you very much;:

MR. VALENTINE: Thank you, Bob. That concludes our slide show, so if we could have the rest of the lights on, too, to catch anybody we can out here. Now to move into some of the othex elements associated with geothermal development, and some of the things one might consider before they get into it, I would like to call on Dr. Tsvi Meidav, President, Geonomics Incorporated, Berkeley, California. Doctor? DR. MEIDAV: Since you said that the slide show is over, I guess I cannot show my slides: 
MR. VALENTINE: I am sorry. I was not aware that you had slides.

DR. HEIDAV: I have a few, so let me show them. Basically, what I wanted to do is discuss some aspects of the size of the geothermal resource and to get an appreciation of what it is, what it could be, and therefore to say how very far we are from the full utilization of the geothermal resource. This rather dramatic picture from Hawaii is, perhaps, a very picturesque demonstration of what is down there under the surface of the earth at depths of anywhere between ten to $30 \mathrm{kilometers} \mathrm{everywhere.}$

These temperatures of 1,000 degrees centigrade are an expression of the tremendous amount of heat, the earth's heat, which is under out feet.

Next slide.

$\therefore$ In the United states, abnormal heat flows are characteristic to the western third of the country, and these white dots are areas of heat manifestation in the form of hot springs with temperatures of higher than 100 degrees farenheit. In general, we may relate these to plate tectonics to the fact that the Pacific plate has been subducting or been thrust under the American plate. Vulcanism has been rampant for the past ten million years in that area. And so, in many parts of the western United States, we have very laxge heat reservoirs at a relatively shallow 
1 depth. A simple calculation that John Banwell and myself conducted some years ago suggested that the total stored heat, utilizable or not, under the United States; is several times greater, about one order of magnitude greater than all the known coal, oil, or uranium that. is available to that depth. That does mean that the heat energy to that depth is utiliazble. We need some concentrated heat in order to be able to make use of it. Next slide. I believe that this schematic is by now, to most of you rather obvious, but the objective of our exploration is to locate those areas that are porous and permeable, where for one reason or another, convecting magma or cooling magma is located at a relatively shallow depth, and to the extent that we are successful, by the variety of geological, geochemical, and geophysical techniques that are available to us, 17 to locate them we are likely to be successful in developing 18 a geothermal reservoir.

Next.

Let us look for a moment, at what is the amount of energy that is available within the earth at various depths, or its various temperature ranges. The units here are on the left, and are given in joules per cubic centimeter of rock And on the right hand side, they are given in thousands of megawatt years per cubic kilometer, gigawatt years per 
cubic kilometer.

And the graph that you see here is the total mechanical energy, available at a given temperature. As we look at this scale, we see that at relatively low temperatures, say 200 degrees centigrade, the amount of stored energy per cubic kilometer, is relatively small. But as we go to the right on this temperature axis, to temperatures of the order of 500 degrees centigrate, and as we get higher towards the melting point of rocks, the amount of stored heat per cubic kilometer is fantistically large.

One cubic kilometer of near molten rock, say rock

at 900 degrees centigrade or so, would contain about 30,000 megawatt years of equivalent electrical energy in one single cubic kilometer. That is a tremendous amount of energy, and it does not take very many cubic kilometers of rock of this type to provide a very large amount of useful energy to the extent that convection of water is present in the area, to the extent that that water can conduct the heat, or to the extent that we have technology to introduce cold water and extract the water as hot water some distance away. By way of example, let me point out that some calculations of the source of heat in the geysers area in northern California suggest to me that there is an intrusion of magma, perhaps presently active, perhaps an activity that may havestopped in the recent geologic past, of about. 1,000 cubic 
kilometers of molten rock, and the geysers field presently

being developed is a mere speck which is a superficial ex-

pression of a tremendously larger heat source below it, perhaps several orders of magnitude greater.

doubt that the present development of geothemal power in the geysers would ever exhaust the heat source. No doubt the stear 
concerned mainly with utilization of either artificially created fractures or perhaps the utilization of natural fractures, i.e., faults that do exist in the earty. calculations indicate that if we have a sufficiently large surface area of these fractures, we can derive a tremendous amount of heat from the so-called hot dry rock.

heat below surface in the United states to depths of ten

kilometers throughout the country is a couple of orders of magnitude greater thatn the total coal, oil or uranium energy known or suspected to exist within the continental united States.

Next.

This is the Cerro prieto plant, utilizing a socalled liquid dominated steam. There are no liquid dominated plants in the United States as of yet, aithough both the Heber and the Niland, and the Roosevelt Hot Springs fields in the United States are likely candidates to be exploiting that type of steam in the near future. And of course, the valles Caldera - I may have forgotten a couple of others. East Mesa probably is a candidate, and maybe one or two more that are still in investagatory stages.

- May I have the lights. 
i

crunch, at present, is. However, it would be very important to point out that geothermal energy is far better suited for direct heat uses than for power production purposes. The best thermal efficiencies that we obtain from any of the presently available porver conversion processes is of the order of 14 or 15 percent.

On the other hand, if we make direct use of the heat for either comfort or space heating, for drying of wood, for processing of products, we can get efficiency as close to 100 percent as we consider practical or economical. It depends only on the quality of insulation that we wish to have and the size of the heat exchanges that we have. But certainly efficiencies of the order of 80 or 90 percent are quite practicable.

Therefore, there is no doubt that a far greater attention to the direct heat uses of geothermal energy must and will be given in the future. Thank you.

MR. VALENTINE: Thank you, Doctor. Before we get going and I make any more comments about the lights, do any of the other panelists have a surprise that I do not know about in the way of films in their pocket or slides?

HR. FINN: I have slides.

MR. VALENTINE: Do you have slides also, Don? Okay. Are you going to include those in your presentation? MR. FINN : Oh, sure. 
MR. VALENTTNE: A person that needs no introduction, I am told -- although I was not here this morning -- I am told that he has already addressed a portion of this audience, anyway. I think we have an opportunity tonight to concentrate on some of his expertise, gathered over the years. Don Finn is managing director of the Geothermal Energy Institute, and Don, you are on.

MR. FINN : Since geothermal is really people -- that is the resource, people who can find it, bring it to the wellhead, sell it and use it -- Tsvi mentioned the Valles Caldera. I see that we are talking to ourselves again, by and large. When men like John Kilkenny, whose company is the only operator in the United States selling steam, and men like Ben Bayliss from Magma, who started this business for us, are in the audience, they should be up here. I should not be up here. If we see a gentleman by the name of Tucker back there, he could tell us all about the environmental. problems as a professional. And Tro Gross can tell us how to find it.

But I guess, taking Hamilton Hesse's admonition that we are supposedly committed but frustrated advocates, these are the people. And we are not that frustrated, really. We own the resource."

May I have the first slide.

It has been the fashion in these proceedings, I know, 
to start with a quote. So I sent to the Library of Congress for interesting quotes. I thought I would share two with you anyway; to set a theme: 1945, Admiral William Lahey of the United States Navy, in the Oval Room of the White House. with fiarry S. Truman: "Mr. President, that is the biggest fool thing we have ever done. The bomb will never go off, and I speak as an expert in explosives." advancement of the arts from year to year taxes our credulity and seems to presage the arrival of that period when further improvements must end." Since I did not know who was going to be in the audience, I thought. I would take that slide. and into Williams College and up to Bennington, Vermont. There are 17 hot springs. The Marquis of Lafayette in 1756 planted a sycamore twig that is now 1,6 feet in circumference. Sycamores like hot water, and that is one way of finding hot springs in the east.

May I have the next slide.

That is the hot spring in Lebanon, New York. So

there is a trickle up there. Who knows what will happen if - 
Next slide.

As a frustrated advocate in Yellowstone, the point being that -- not so much Yellowstone, but how about Nit. Iassen, how about the wilderness areas? We have got to focus with the Forest Service to open up the forest surface lands, if we are ever going to get into Fremont County, Idaho, into Mt. St. Helens, into the biggest playes. This is an institutional problem. We have got to face it. The resource is there, but can we get at it?

Next slide.

We have the leases, remember. There is a frustrated advocate who took $\$ 10$ million of Mr. Howard Hughes' money, and according to "The Goyer" (?), McNorton has three or four hundred million dollars' worth of the resource; had it at the well heads in 72 . This is 76 . Luckily, they broke ground last week and on May 1, 1976 PG and E says, at 15 mils a kilowatt hour on a 60 megawatt machine, gross 55 , and that his client will get the money out. He has 15 percent of that, John Callan.

Next slide, please.

So it can be done. The geysers, for those of you

22 who have not seen it -- this is an old picture I like. Next slide.

And here is what Ben Bayliss and John Kilkenny have done. They have taken something and made something out of it. 
Dr. Hess -- rightfully so, it is a beautiful area, really, it is remote -- and he lives up there. He does not want to have the smells. So does Mr. Tucker -- or the noise. And I can tell you that everybody is concerned about that. and others, perhaps the utility involved would not have been moved to do the work it has done. But it is doing it.

I can also tell you that if it was not for Dr. Hess Next slide.

Just to give you an idea of well spacing. Next slide. That is what it used to look like before Mr. Kilkenny and his associates and colleagues figured something out about reservoir engineering. You do not have to do that any more.

\section{Next slide.}

Another view of it.

And the next slide.

You have seen that one.

Next slide:

Just some of the technology that Ben Bayliss could taik to you about.

$$
\text { Next slide. }
$$

Cerro Prieto, the silencer.

Next one:

Cerro Prieto again, the cooling tower. Next one. 
This we might stop on. This is what the USGS said

in 7-26. This is what the Vational Research Council is going to say in January, 1977 , according to the present draft. they are going to cut it off at 180 degrees centegrade; rather than 150 degrees centegrade, on the theory that we do not have advanced technology. That is, we do not have total flow machines, helical screw machines, bladeless turbines, KRRV's, or binary cycles, that all we have is the dry steam technology.

Therefore, on a 180 degrees centegrade base, they are going to say on the Iiquid dominated resource, 2,525 quads; vapor dominated, 53 quads, only the geyser. Mr. Joel Renner (?) of the USGS tells us we do not have any dry steam outside the geysers. Normal gradient, 180,000 quads; dry hot rock, 150,000 quads and zero from the lavas. Next slide, please.

This is my talk, but no time for it. Just to give you an idea, I think that the business is a mining man's business for exploration until you come to drilling the well and operating the field. Then it is the oil man's business. Next slide, please.

I also think the economics are the mining business, and that is what that means to say. We do not have the time to go into it. 


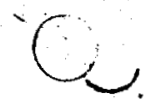

from industry's point of view. This is what we have to do. So let's go through them.

Just go through it, silde by slide, please.

I think the speakers downstairs were wrong, and I think Hamilton is wrong. The oil companies do not control this business. The law says that any one person can only have 20,480 acres of Federal land in any state, and that includes Union oil Company. The vast majority of lesees are not oil companies. That 20,000 acre limitation hurts everybody. It has got to be changed.

Next slide, please.

If we are going to have the Federal government say that because two men who are out looking for a resource:overlap a leasing application in the same area, and that makes it a known geothermal area, and therefore it has to go to competitive bid, we are kidding ourselves. We have seen the result of it. We are just not going to have a leasing program. We are not going to get the land out, and it is not going to get developed. That has got to get changed.

Next slide.

On the one hand, we are between the horns of a great dilema. Unless we get the leases out, we do not have something to drill on. We do not have a tax status. We cannotraise the money to do it unless you are Union oil Company and 
can take your profits that you made in the oil business in the $30^{\prime}$ 's and $40^{\prime}$ 's and pour it into geothermal these days.

When; as, and if the business ever gets off the ground. But remeniver that industry has applied for those leases and owns. the resource, unless somebody wants to take it away from them by. some fiat.

Next slide.

If we are going to be stuck with the Congressional

attitude of "let the courts decide who owns geothermal, the feoffstate owner or the patentee, or the Federal government as a reserve mineral owner, and we are going to litigate this

for the next three to five years, unless we have an escrow agreement both inside and outside of KGRA's; we are going to

block development, certainly at the geysers, where development is blocked because of these legal -issues:

Next slide, please.

I have referred to the -problem, in my opinion, restricting geothermal development today, the fact that the congress has decided - or it is the Ford ndministration, and amazingly, Sen. Ted Kennedy and the Ford Administration have formally opposed tax relief for the geothermal industry. Therefore, if you are going to go 
into the oil and gas laws, we may not currently expense our intangibles. We must capitalize intangibles and capital items. He cannot depreciate them before production. And ye must pay ad valorem taxes in the meantime, even though you do not have revenues to pay them. The Administration and the rreasury Department says that if this was changed, the operators of the geysers would have a windfall, and the business does not need incentives.

I have to say I think much of the Ford Administration. I have a minute left. I would just like to disagree with Dr. Iless, if I respectfully may. I think llamilton is a great theologian, but I do not think, really, that he is fair when he tells of the environmental horrors of geothermal. May I have the lights, please. The simple fact of the matter is that I think Richard Bowen's analyses, both at the Pacific Conference, and Dr. Ott in Kruger's book on geothermal energy, make the point that this is the environmentally preferrable resource that we can have today. We do not know where solar is going to 20 go yet.

There is no mining, no milling, no ore processing.

22 There realy is no fuel transportation, storage, or fabrication. We do not have radioactive waste disposal problems or particulates. We have $\mathrm{H}_{2} \mathrm{~S}$; but we have Stratford process, and it is going to be on unit 15 thereafter, and the engineers say 
it is going to work. I hope $M r$. Tucker believes that. He may have a few reservations until he sees it working in Sonoma. It helps clean up the smell that comes over beautiful

I. think there is a balance, however, on the environmental side of geothermal. I would point out that according to David Howell, the computer whiz of the geothermal business, that if we had 10,000 megawatts on. what Dr. Meidav predicts is a very vast land area -- I think it is 378,000 acres and the KGRA is extended -- if there were 10,000 niegawatts, that the ad valorem taxes to the county would be six-and-a half billion dollars - billion dollars - over 30 years. If we had intangibles on that, it would be $\$ 51$ million in intangible deduction to get there and the depletion would be $\$ 14$ milion. That is the simple tale. Wy time is up.

I had a prepared statement that was a little more vigorous than I have said here today. I would just say that ERDA is a mixed bag, as I see it. I am delighted to see the new program that Jim Bresee has brought out on the non-electric. I think that is one of the best things they have done. With $\$ 2$ million dollars they are, I think, going to have one of the most successful little programs in the world. And yet we see $\$ 4$ million being spent on the administration of a loan guarantee program. We do not see an application in there. 
So there is that problem. I think we just need some time and effort and people, and hopefully, if the peanut vendor becomes the president, and he collapses what Mike McCormick, I am told, says -- "He kept FEA alive to give ERDA some competition" - and he winds them all together, wherever this goes, hopefully we will see some-continuity in the programs and some real encouragement of industry.

For those of you who have not seen it, I commend to you - it is a fine piece of work. It is free, too. It is available from the Fish and Wildife service in sacramento from Bill spaulding. It was really written by' Jim Kanig (?). And it is the finest published, up to date, as of December 175 piece of work, explaining what geothermal is, and then step by step, mapping the KGRA areas and giving a time table for development. And Jim, without violating any client confidences 
has. done a supurb job of saying, "Look. This is what industry

2 has." And I would make the point, and I disagree with the distinguished padre from Fresno who remarked downstairs that this conference seems to be rigged -- if there is one thing this conference is - there are no major oil companies participating in it.

\section{I criticize the conference because the people who} own and are going to develop and operate the resource are not here. I do not see how ERDA can help industry if they are not going to have them here. Maybe it is not appropriate to have industry at this particular kind of meeting. This is for the public and the public input. . But I come back to ownership, being a capitalist, and knowing the people who own vast tracts of land and what their plans are, I would say that geothermal is a bit of a submarine.

\section{- There are some events that are going to happen in} the next few months that will startle a lot of people. But on the other hand, the industry as such is stalled dead in its tracks because, as the congressional office of Technology assessment has stated in its comparative analysis of the program, it really is not a technological problem' for the dry steam and the wet steam. It is an institutional problem - the taxes, the environmental problems.

Certainly. I commend ERDA for the geopressure program. If that is a winner, we are all the better off for it. Thank 
you

MR. VALENTINE: Thank you, Don. I was afraid you

were not going to leave any questions unanswered there for

a second. But we are on our way, and John Arlidge, the

Assistant to the Vice President for Nevada Porver Company is

here to discuss some of the experiences that they have had

with ERDA in the geothermal program, I think. John?

8

9

MR. ARLIDGE: It is not quite with ERDA. Don

caused me to reflect a little bit. We are sitting here talking to ourselves again. I met Don Finn, the second man you always meet when you look at geothermal, about the early 1960's.

And as you saw, Don is a baseball, hot dogs, apple pie, geothermal, and motherhood person. Tsvi, I met him with Bob Rex working in Imperial in the '60's. I first ran across Hamilton Hess down in El Centro about 1968. He had about a 40-minute dissertation on hell.Eire and brimstone.

When we got through, we figured if we developed geothermal, our families and ourselves would be banished from the Garden forever. Denny. I met in 1974 in Santa Barbara, discussing legal problems, of why geothermal is not developing: Jim Bresee and $I$ were in Salt Lake City yesterday discussing problems, why isn't geothermal developed.

Everyone knows, I think, that there is an energy crisis, and it is severe enough that we should be taking advantage of each of our energy resources. Geothermal energy 
is a potential source for the utility industry. It has been estimated by some that it could provide one percent or even 100 percent of our generation requirements between now and 2000

5

6

I do not believe it can provide 100 percent, but if it can provide one percent, we should develop it. Incredible as it may seem to you, under Federal policy and regulations, it will not be developed. The Federal government owns and controls virtually all the potential geothermal areas in the United states. After 25 years of legislative history, it passed the Geothermal Steam Act in 1970. Aimost six years have passed. Out of the 300 milition acres controlled by Federal ownership, none has been produced.

Federal and state governments are still arguing over who owns it, and regardless of who owns it, who is going to control it. The Federal government's environmental laws, tax laws, and the Federal and state disputes will prevent its development. Some applaud this. It is highly doubtful that the industry will find that it is beneficial to develop this to any significant level under the existing stringent and unrealistic regulations.

The Geothermal steam Act differs greatly from the Mineral Leasing Act, as Don pointed out. Further Federal regulations forbid the filing of a power plant site until acommercial field is developed. No one in their right mind wi 
devote the time or the energy or the money to develop a commercial field without at least reasonable assurance that a power plant site could be obtained.

Two further restrictions, if there were no other problems, would preclude utilities from participating in this resource. They are the lease terms which call for readjustment and possible cancellation at ten-year intervals. The second one is that Federal agents have the authority to arbitrarily shut down a power plant without notice.

The possibility of such unilateral and arbitrary

11. actions are, to say the least, hardly consistent with the

12 tremendous long-range planning and huge investments denanded

13 by a successful utility operations. As if all that were not enough, we still face the usual environmental problems --

15 the noise, odor, land use, aesthetics, disposal of condensates 16 et ceterá.

The development of this resource, as in other re-

18 sources, will call for realistic compromises between environ-

19 mental desires and energy needs. And so, as desperately as

20 we need to take advantage of geothermal energy, nature's

21 gift, we certainly are not encouraged to do so under Federal

22 policy and regulations. We must come to a general agreement

23 to force the Federal Government and state agencies to modify

24 their policies and regulations so that we can develop geo-

thermal energy and all other energy sources needed. Thank 


\section{MR. VALENTINE: In concluding the formal part of} this program, and just prior to questions by the audience, or discussion, I should say, from the audience -- because I think there probably or may well be considerable discussion between members and participants on the panel, along with members of the audience who are equally as distinguished. I would like to present Jim Bresee, Acting Director, Division of Geothermal Development for the Energy Research and Development Administration, to offer some observations of his own. MR. BRESEE: Thank you, Mr. Chairman. I decided to wait until we had concluded the remarks of the other participants and see if I could not make a few summary comments and take as little of your time as possible to get through them, so that we can get on into the more interesting portion of the problem. As far as I am concerned, the real benefit of this program will begin when we do have a chance to exchange ideas with those of you who have sat through a long day and put a lot of time into participation, and I am sure, have things to offer us. I look forward to that portion The geysers field,

22 which was described by several participants, is the only field in the United States presently under development:

24 There are a little over 500 megawatts presently at that site, 25 but with rather firm projections to go to 1,500 megawatts by 
1985. At 500 megawatts, it represents the largest single development in the world. You might be interested in knowing that there are eight other countries in the world that use geothermal energy for electric power production, and several others that use it quite extensively for non-electric use. more important application of the energy resource. We are very delighted when we find resources as high as 200 degrees centigrade to exploit. This is very old, very low temperature cation.

\section{use looks like it may turn out to be, in the long run, an even \\ I would agree with Tsvi leidav that non-electric} resource, in terms of electric power generation, where nodern power plants frequently exceed 600 degrees centigrade, when
they are fossil fueled.

\section{We are dealing with, therefore, very low energy} efficiencies for electric power production. But combined electric and non-electric applications may be quite significant. It is said that the non-electric applications in the world today exceed the electric by a factor of about five. It is very hard to pin down the total amount of non-electric applications when you consider you could include all the spas and health resorts, in the world as a non-electric appli.

And just how efficiently the heat energy is used

24 in these facilities are not quite clear. But in this country 25 at least, we now produce one tenth of one percent of our 
electric power from geothermal energy. I vould agree that going to one percent -- in other words, increasing by a factor of ten -- the percentage utilization, would be a big step forvard. I am optomistic enough to believe that we can do better, and that on a national basis, by the end of the century, we may actually reach several percent, in the range three to five percent, if we can get through both technical and non-technical obstacles in the way of the development and carry out the development in an environmentally acceptable manner.

That national figure may be a little misleading, because as several people have observed, we are talking about a western development, principally. It does appear that the 15 western states - and by that, I am including Texas and Louisiana because of geothermal pressure -- but the 15 western states, on a percentage basis, may make use of geothermal energy on a much larger scale than this few percent nationally In fact, it is entirely possible that the state of California could produce as much ten percent of its electric power from geothermal energy. This, in a state that uses so much oil now, oil and natural gas, could be a tremendous improvement in the electric power base.

I might mention that the Federal program's geotherma budget has been rising rather rapidly. In fact, in the President's budget of fiscal 177, geothermal energy as an 
energy technology received the greatest percentage boost of any of the energy technologies, all the other, non-nuclear and nuclear, over 40 percent. increase between 176 and 177 .

Our budget, after Congressional action, which was -

also increased another ten percent, will exceed $\$ 50$ million.

6

7

8

When $I$ began work four years ago in geothermal energy in the

Federal budget, the total Federal budget at that time was

$\$ 5$ million. So there has been some progress, at least, in

trying to get more of the limited energy resource dollars into this very important technology.

At a meeting that several of us attended during the

last couple of days in Utah, where we discussed with indus-

trial representatives and state and local government repre-

sentatives the problems in the development of geothermal

energy, there was an announcement made which pleased me a

great deal' and which many of you might not have heard: that

is, that the Magma Power Company is planning to build a ten-

megawatt pilot plant, based upon a liquid reservoir at East

Mesa, within the next couple of years.

They do expect to have this power plant in operation

producing power by about 1979. So it will give us a bit of

a let up in getting this under-utilized liquid dominated

resource. The earliest that I would expect a commercial 
tutional issues that Don raised. His comments are certainly well taken. We spent a little bit of time at the Utah meeting talking about some new approaches that ERDA has been undertaking in cooperation with other agencies to try to reduce some of these non-technical obstacles to the development of this resource.

For example, the Department of the Interior has agreed, as a result of interagency discussions, to recommend to the next Congress that the acreage limitation that Don referred to, be raịsed by at least a factor of two, up to above 50,000 acres per state. We also expect to have regulation changes which reduce the impact of overlapping lease applications in terms of producing KGRA's. We hope to greatly speed up the leasing of Forest Service lands. We have been working closely with licGuire, Director of Forest service, and are writing letters to his boss, Secretary Butz, and have talked to the congress about trying to get additional funds into the environmental assessment activities necessary to get those Forest Service lands leased.

ERDA put about $\$ 100,000$ of its funds this past fiscal year into doing one special study at Long Valley which is predominantly Forest Service land, in order to get that particular leasing program under way. It should begin early in 1977. 


\section{I was very disappointed -- many of us who are trying} to see this energy technology grow -- I was very disappointed with the decision of the Congress to eliminate the Fanin Amendment from the Tax Reform Bill that has just been completed. This vould have provided some of the tax relief that other energy technologies have had, and which geothermal needs even more, because of the much longer period between the beginning of geothermal development and the beginning of cash flow. That amendment was stricken from the tax bill and apparently is dead for this session.

In the meantime, we have gone ahead with Treasury and have gotten them to agree to recommend changes in the tax law which would provide approximately two-thirds of the financial benefit that would have accrued from the Fanin bi11. This will be also introduced into congress early next year.

A few words in defense of the loan guarantee -- particularly since one of the major participants in administering this program, Diane Nastish, is down in the front row, and I know that she and others here at the san Francisco office have put an awful lot of effort in trying to get the program

22 off the ground. It does appear that it is finally making headway. When you consider that it was published in the "Federal Register" in May and became effective in June, and25 we are now just barely three months into the progran, the fact 
that four or five applications are to be filed within the next several weeks I think is an indication of movement, and $I$ commend the San Francisco office for putting in the necessary. time to get such a complex but important program rolling. I think that is enough general comments about geothermal. energy trom my side. I am very interested in comments from your side.

of you still remaining, and of those of you remaining, those

MR. VALENTINE: I am directed to point out to those

11 in the room: However, I would think that there is not enough

12 ambient noise to demand you use those unless your voice is

tremendously hoarse or low. I would like to, at this time,

14 Open it for your questions of nembers of the panel. And

please also direct your 'questions to a particular member of

16 the panel, if appropriate, or at. large.

And time allowing, if members of the panel feel

that they would also like to comment on a matter or become involved in brief discussion on an issue that may be confusing,

20 please do not hesitate to do so. Questions?

That is amazing. You know, on occasion, I had an

opportunity to be involved in debates on the nuclear initiative

23 And if there is one thing I gained from that experience, beside

24 bruises, it was that geothermal is going to be the answer.

And now I am confused from what I have heard. So let's go. 
Yes.

MR. HARPER: Viell, a lot of comments have been made

about how you come to these meetings and talk to each other. Well, you ain't talked to me. I am Carl Harper. I an on the legal staff of the Lake county Energy Council. He are a 1,400 member group who represent people very concerned about development in Lake county. The primary thing that concerns us is what is happening in Sonoma county right now.

In other words, you have developers and you have the utilities. The developers come and sell you on the project, and there is no doubt that many of them are excellent companies and mean exactly what they say. But then it is the utility that makes you live with it. PG and $E$ has refused to change its dirty diapers in Sonoma, and we smell the $\mathrm{H}_{2} \mathrm{~S}$, not just a little - a lot. And this is a real problem. We have nöt made much headway.

It may just be that our board of supervisors is going to have to sue sonoma. It may just be that that is the way it is going to have to go.

One of the real problems that I want to address to

21 ERDA is the fact that - what is it - four-and-a-half million dollars plus has been sent into Imperial county, and so far 23 we have gotten about $\$ 50,000$ into Lake County. The group that I represent is not just your knee-jerk environmentalists. We are for intelligent development, but that means a lot of 
things to a lot of different people. To some people, intelligent development means, put a plant in somebody else's back yard, and get the energy in for yourself.

We are definitely going to make sure that it is

done right: There are good people in Lake county. We have an excellent Planning Commission. We have air pollution control officer who is one of the best in the state -- maybe the best in the state. We have some good Young Turks working for the planning staff. But you have got to put money into our county. We are a poor county. We cannot even give our deputies a raise. It is a very, very poor county. ERDA and the Energy Commission have got to take up the slack, because not only do new technologies have to be shown to the people in Lake county -- and that is going to require development, because we have not seen anything in Sonoma that makes us want to have it in our county.

But not only that, it is also a mammoth planning

task. We are sitting on top of a tremendous resource. I waint

19 to see it developed. I want to see people make money. I want

20 to see energy come out, but it has got to be done right. And

21 it is going to require a mammoth planning process. It is going to require dollars. And that, gentlemen, has got to come from the Federal government and the state government, because it is the people who are ultimately going to benefit 25 from this energy. 
So I just would like to ask ERDA what you have in mind for Lake county.

MR. FINN: Could I just reply to the preliminaries on PG and $E$, and so forth?

MR. VALENTINE: Yes. Go ahead. Sure. MR. FIIN : Mr. llarper, I am a member of the Geothermal Association of Lake County. As far as I know, the vast majority of people who own property in the county, who are registered voters and taxpayers, are in favor of geothermal, through my association with that committee.

MR. HARPER: Do you live in Lake County?

MR. FINN : No, sir. I do not live in Lake county,

but I visit there and am delighted to do so. I do not know how long you have lived in Lake County. Not too long, I would suspect, although I do not know you. The newcomers to the county - and who they may be -- and I take that some of your members are associated with the Dawn Horse Community. We know them of polk street here in San Francisco, and up there, I guess it is Seagull springs.

... We have run into them. They make statements like you have made which are, I think --

MR. HARPER: Who is "they"?

MR. FINN: Members of your council, like yourself. The Dawn Horse Community people make slanderous statements, outrageously unfactual statements. When you say that -- 
MR. HARPER: Who is "they"? -

MR. FINN: The members of your council, six.

MR. HARPER: There are two members of the Dawn Horse Community that are members of a 1,500 member council. What are you trying to get into, Mr. Finn?

MR. FINN: Your statement, sir, your completely nonfactual, slanderous statement that PG and $E$ has not changed its dirty diapers. If you do not know that the california Public Utility Commission has ordered and is supervising PG and $\mathrm{E}$ to retrofit units 1 through 10 to clean up the $\mathrm{H}_{2} \mathrm{~S}$; then you do not know what you are talking about. And if you do not know that units 15,13 , and now they have filed for . 16 and 17 , are going to be outfitted with the stratford process to clean up the $\mathrm{H}_{2} \mathrm{~S}$, and you represent that $\mathrm{PG}$ and $\mathrm{E}$ is not doing what it has been told to do and is not taking advantage of the best available known technology known to man, and you seem to be against - - and are not offering us anything for - I question your motivation. I question who you really represent and talk for.

I do not agree with you that ERDA has to pour money into lake county. As I pointed out, the resource is there. The income from the taxes are going to be enormous - for what, about 30,000 people in the county? MR. HARPER: 25 . MR. FINN: And again, I say the property owners -- 
1

Lake county is virtually leased, across the county, for geothermal development. The landowners are receiving rental revenues for the leasing of those properties, and I do not agree with you that things are not going well. When the CPUC and when the air and water quality regulators of this state have issued all the permits necessary to build unit 15 , and are requiring $\mathrm{PG}$ and $\mathrm{E}$ to retro-fit its units, they are doing it as best any good engineering skills can do it, I think the evidence is that industry will do what they can practically and humanly do, with good intentions.

I am no spokesman for PG and $E$. I am on the other side of them: I want to see them move faster than they do. But they do a great job, I think, for a very large organization. I just want to reply to you in that way, sir. MR. HARPER: The only comment I have to that is the fact that the Lake County Board of Supervisors is very progeothermal, and they are considering sueing Sonoma County for the fact that $\mathrm{H}_{2} \mathrm{~S}$ continues to come over. Over a period of years, we have griped, we have threatened them, and it has continued. If you would like to hear that from Fain Tucker, you can hear the same thing from him.

MR. FINN: I read the "Santa Rosa Democrat," and that is just politics. It is good defense to the lawsuit, and MR. HARPER: It is not good politics, if you live there and you smell.it. That is a simple fact. 
$(3$

$\square$

1

2

3

4

5

6

7

8

9

10

11

12
.

f PUC order supposed to be -- it is effective, in that they are doing it, but when are they supposed to have it done?

MR. VAIENTINE: Excuse me, if I can interject just

for a second. The discussion is interesting. When is the MR. FINN: They have a review every few months, and they are testing a variety of systems that are not all working that well. They have gone through several of them, and they have engaged all sorts of consultants to get the best available engineering advice as to how to retrofit these things. I think they have a variance from - they are exceeding the air quality standard, which is not a health standard. It is a smell standard; because you can smell it. It has to be eliminated, but not because it is a health hazard in any way.

I think John Kilkenny may know better than $I$. But. I think they have three years, a three year time table. But' they have just got to, or they will shut them down.

WR. HARPER: It is the local air pollution control district that he is talking about, not the --

MR. FINN : No. I am talking about the California . Public Utilities Commission. They have an outstanding order. MR. HARPER: That is on unit 15 . MR. FINN: All units. 
question is, how much money is ERDA bringing into lake county, and when is it going to start coming?

HR. BRESEE: I have had several conversations with Fain Iucker, and I will be taking part in your next conference in October: I look forward to having continued discussion with him and with you at that time.

Fain and I have talked about this problem of lack of IRDA funding directly to the county. I urged him on several occasions to prepare some sort of proposal which we could deal with, and I still look forward to receiving one. In terms of what funding ERDA is applying to Lake County's problems, it is considerably more than the $\$ 50,000$ you quote. I would be glad to go over in detail the environmental studies which we feel will be useful in trying to help solve what I am sure is a very serious problem from your standpoint. I look forward to discussing it further with you when $I$ am there in October.

MR. HARPER: One of the points that we would like to get across is that it is not just the technology that is involved. It is the planning process.

$$
\text { MR. BRESEE : It was that side of the needs of the }
$$

22 county that Fain and I discussed over the phone. And I guess

23 when I am up in October we will have a chance to go over it 24 in more detail. But we would like to help. We recognize that 25 there are problems there. The State Energy Commission also 
recognizes that there are unsolved environmental problems associated with past developments, and I am sure we all want to move as rapidly as possible toward a solution of those problems.

MR. HARPER: Not just trying to stress the negative in terms of environmental problems that are unsolved, but trying to stress the positive -- and that is whenever you go about development, you want to do it in the right way. That requires planning. In lake county, you are talking, like Mr. Finn says - virtually the entire county is leased. You cannot have a power plant on every single leasehold, so there is a tremendous planning job that has to be done there that cannot be done with the resources of this county.

MR. VALENTINE: Thank you. Another question? You guys do not have any problems. What are you telling me? There are not any questions.

MR. MINER: I was curious to know how many loan guarantee applications you have had to date?

MR. BRESEE : That is an easy question: none. The first applications should be coming in within a couple of weeks, and it is my understanding there will be about five between now and the end of october.

MR. MINER: You made a point that you are changing the regulations?

MR. BRESEE: There have been a series of identified 
problems with the existing regulations. I am sure they will be changed. We have not'started any formal procedurés to. . change them. But particularly as we go through the actual processing of these first applications, we will get a better idea of where there are difficulties or ambiguities or uncertainties.

Incidentally, any of you who have had connection with the loan guarantee regulations know that they were first issued in draft about a year ago and went through three or four draft reviews using as much advice from industry, from county representatives, state governments, and so forth -and still, as you know, governments are less than perfect, and the regulations, I am sure, need improving. But we will gradually try to get a better set of regulations out. SPEAKER: How is the $\$ 50$ million funded down into the various categories?

\section{MR. BRESEE : Approximately $\$ 15$ million in research} and advanced technology, which includes resource assessment work; approximately $\$ 20$ million in utilization programs, including such things as the dry hot rock, geopressured

21 activities; there is about $\$ 5$ million in work in, environmental institutional, regulatory programs; there is about $\$ 4$ million in expected costs associated with the loan guarantees which, incidentally are not administrative expenses. I would like to correct that misunderstanding. These are expected defaults 
during the first year of operation from i $\$ 30$ million total estimated default over a period of the lifetime of the loans, totalling $\$ 200$ million.

Three numbers -- let's see if I can explain them. of loans the first year. And of that, the expectation is that there may be $\$ 30$ in defaults, a one in seven ratio, and that of the $\$ 30$ million, $\$ 4$ million will occur the first year.

Those are descending estimated numbers. I am not sure $I$ am up to the full $\$ 50$ million, but I will try to correct it when

would be $\$ 30$ million outside of the National Labs. I would

like to explain the pattern changes in ERDA funding. I think it might be eaifying.

The Eirst year of ERDA's existence, which was fiscal $75, \$ 20$ million was spent, $\$ 15$ million in the National Labs. The second year, $\$ 32$ million spent, $\$ 19$ million in the

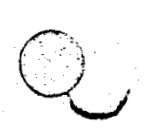

MR. MIINER: How much of the $\$ 50$ milition goes to National Iaboratories?

\section{MR. BRESEE: Approximately $\$ 20$ million. There}

National Labs. The third year, which is fiscal $17, \$ 50$

million, approximately the same, \$19-20 million. Our policy

is to maintain laboratory funding level and to put all the

increases into university and industrial contract work.

MR. MINER: Could you give me a percentage figure on 
how much, percentage-wise, goes to private industry?

MR. BRESEE: Yes. I can take those numbers I just

gave you. The first year it was 25 percent; the second year, it was approximately 38 percent; the third year it will be 60 percent - increasing percentages.

MR. MINER: To private industry.

MR. BRESEE: To private industry.

\section{SPEAKER: I have heard some comments on a new re-}

gional perspective that IRDA is looking at. Could you perhaps comment on the status of that question, or how it is going to be used?

MR. BRESEE : Yes. As the program began, a good deal of it was activities inherited from the AEC and from NSF. It became obvious after about a year into the program, that there was a need to shift our emphasis toward what has been called regional or field planning so that we would look, with the help of local or regional entities, the San Francisco operations office of ERDA, the Jet Propulsion Laboratory, SRI, the california state Energy Commission, for example, all working together to try to determine to try to determine what the possible geothermal growth scenario in California might be, looking locally at the possible future of the energy here. We are doing the same thing in the Northwest. We are starting the same program in the Texas-Louisiana area connected with geopressured. We will be starting a similar 
program in the Great Basin states. Each of these planning activities, then, has associated with it requirements, technical requirements, and field experimental activities, which then demand resource planning in terms of Federal involvement. So we are trying to go from a series of regional scenarios developed in conjunction with the state and local governments, as well as industrial groups, back to planning the allocation of the limited Federal funding. This is a change that has been going on over the past six to eight. months. We are also, at the same time, contemplating a reorganization of the division to make it structurally easier to carry out this type of activity.

It is part of a general effort, I think, in ERDA to decentralize its management as much as possible and to take advantage of knowledge on a local level, and management capability on a local level, to improve our priority system. MR. VAIENTINE: I think we are getting close to closing this up, and before we do, just for my own references, I would like to have an indication of how many people yet remaining in the room have no professional interest in geothermal, but are here because they are what we would call a concerned citizen.

( 5 or 6 members of the audience raised their hands.) MR. VALENTINE : Okay. Thank you. I was just won- 
MR. FINN : Can I add one comment to something Jim

has said?

MR. VALENTINE: Yes., Don.

MR. FINN: Jim referred to PG and E's plans to have

1,500 megawatts at the geysers by 1985. I have PG and $E^{\prime} s$

6

latest prospectus, which is an amazing prospectus. They are

offering seven-and-a-half million shares of stock \$23, I

guess the largest stock offering ever made in this country.

It is the first time they have ever sold public stock, too,

since they have gone public.

The latest count is 2,300 megawatts by about 1988 ,

1685 scheduled for installation, they are going to be ordered,

and the rest in a planning stage awaiting Union oil and

others to find a little more steam, as is thought can be done,

which tells you something about $P G$ and $E^{\prime} s$ ability to predict

16 the future a little bit.

And I just might say that in reading the prospectus,

I note that although Jim is right, there are only $5.02,000$

kilowatts net, 522 gross, installed at the geysers, that is

5.7 percent of the generation of $\mathrm{PG}$ and $\mathrm{E}$ 's system, while

21 nuclear is only .6 percent. On the other hand, according to

the prospectus, we have got 2,000 megawatts of nuclear at

23 \$985 million scheduled for 1977 at Diablo canyon. Those

plants will never come on in 1977, because of the seismic - 
on that investment and the need to purchase additional power

is going to raise that effective cost, perhaps up to $\$ 1,000$ a

kilowatt before they are through, and they do not know whether they are going to be able to meet the seismic safety standards. The uncertainty is devastating. going to go? I think it is going to follow this. PG and $E$ tells us that they have dipped into their treasury stock and they have exchanged 767,000 shares of $\$ 23$ stock carrying $\$ 1.88$ a share divident, for a 35 percent interest in 9.1 million pounds of uranium. That is $\$ 45$ a pound in the ground, and they hope that Union Oil Company, who are the managers of that uranium project, can pull it out.

If they are going to start buying uranium in the ground and coal in the ground, as they have done in Utah, perhaps it will not be too long that we will see some of the utilities buying steam in the ground.

MR. MINER: What is the payoff in mils, presently,

the rate increase?

MR. FINN : PG and $\mathrm{E}$ is estimating $15 \mathrm{mils}$ of

21 January $1,1978$.

MR. VALENTINE: You know, I am told that some of

these problems are best solved, not in a parlor sitting

24. theater-style, but in a pub sitting in a line, and I would.

25 like to invite everybody to continue their conversation 


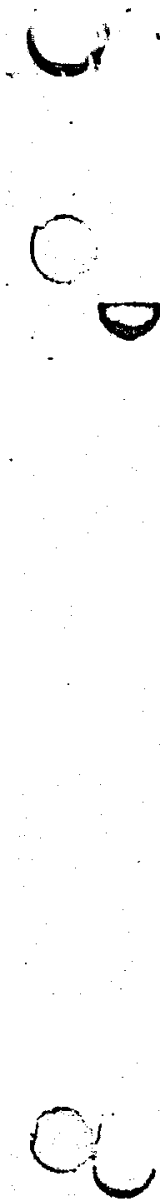

1

2

3

4

5

6

8

9

10

11

12

1.3

14

15

16

17

18

19

20

21

窎

o 23

24

25

informally, seeing that it is past $110^{\prime}$ clock, and thank those of you who have had the interest to participate in this portion of ERDA's discussion. Thank you.

(Whereupon, at $11: 10$, the workshop was adjourned.)

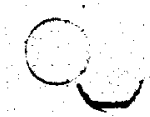

